\title{
PELATIHAN "BASHO KANEL" BABY SHOES KAIN FLANEL SEBAGAI BEKAL WIRAUSAHA MANDIRI BAGI REMAJA PUTRI PANTI ASUHAN SITI HAJAR MADIUN
}

\author{
Vera Dewi Susanti ${ }^{1}$, Siti Qomariyah Nur Hidayati ${ }^{2}$, Arisma Noviana Putri ${ }^{3}$ \\ 1,2,3Pendidikan Matematika, Universitas PGRI Madiun, Indonesia \\ 1era.mathedu@unipma.ac.id, ${ }^{2}$ sitty.nur62@gmail.com, ${ }^{3}$ arismanovianaputri@yahoo.co.id
}

\begin{abstract}
ABSTRAK
Abstrak: Pekerjaan sebagai pengusaha atau wirausahawan mulai diminati banyak orang. Hal ini menjadi penting sebab berwirausaha memiliki keuntungan lebih dibandingkan menjadi seorang pegawai kantor maupun buruh. Wirausaha mengajarkan aspek penting berupa kreativitas dan keberanian. Wirausaha memungkinkan seseorang membuka lapangan pekerjaan bagi orang lain dan tidak lagi sebagai pencari kerja. Panti Asuhan Siti Hajar adalah panti asuhan yang berada di Jalan Jonggang, Mangunharjo kota Madiun. Anak-anak di panti asuhan tersebut selama ini belum mendapatkan bekal ilmu keterampilan yang nantinya dapat memandirikan mereka kelak. Saat ini remaja asuh putri di Panti Asuhan Siti Hajar Madiun belum memiliki keterampilan berwirausaha di karenakan terbatasnya biaya yang dimiliki pengelola panti asuhan untuk memberikan materi keterampilan, sementara keterampilan adalah salah satu aspek penting untuk bekal kemandirian mereka saat dewasa kelak. BASHO KANEL merupakan pelatihan kewirausahaan dan ketrampilan bagi anak-anak yatim yang kurang mampu dengan memanfaatkan kain flannel sebagai bahan pembuatan sepatu bayi sebagai bentuk kontribusi nyata dalam usaha memandirikan dan memberdayakan mereka. Hal itu kami lakukan mengingat perbuatan menyantuni anak yatim dalam hal memberikan ilmu kemandirian berwirausaha dan ketrampilan adalah salah satu usaha yang sangat dianjurkan oleh agama dan sangat dibutuhkan oleh anakanak tersebut. Selain itu, kelak mereka akan mampu membuka lapangan pekerjaan baru yang dapat menyerap orang lain yang senasib.
\end{abstract}

Kata Kunci: BASHO KANEL, Panti Asuhan, Wirausaha

Abstract: Currently employment as entrepreneurs or entrepreneurs began to demand a lot of people. This is important because entrepreneurship has an advantage over being a worker or a worker. Entrepreneurs teach important aspects of creativity and courage. Entrepreneurship also allows one to open employment for others and no longer as a job seeker. Siti Hajar orphanage is an orphanage located in Jonggang Street, Mangunharjo Madiun city. The children in the orphanage have not been able to obtain skills knowledge that will be able to establish them later. Currently, foster adolescents at the Siti Hajar Madiun Orphanage do not yet have entrepreneurship skills because of the limited cost of orphanage managers to provide skills materials, while skills are an important aspect for their independence as adults. BASHO KANEL is an entrepreneurship and skills training for underprivileged orphans by utilizing flannel fabrics as a shoe-making material as a form of tangible contribution in an effort to independence and empower them. That we do remember the act of sponsoring orphans in terms of providing knowledge of self-reliance and entrepreneurship is one of the business highly recommended by religion and is needed by these children. In addition, later on they will be able to open new jobs that can absorb others who fared.

Keywords: BASHO KANEL, Orphanage, Entrepreneurship 


\section{A. LATAR BELAKANG}

Saat ini pekerjaan sebagai pengusaha atau wirausahawan mulai diminati banyak orang. Hal ini menjadi penting sebab berwirausaha memiliki keuntungan lebih dibandingkan menjadi seorang pegawai kantor maupun buruh (Mentari, 2018). Wirausaha mengajarkan aspek penting berupa kreativitas dan keberanian. Wirausaha juga memungkinkan seseorang membuka lapangan pekerjaan bagi orang lain dan tidak lagi sebagai pencari kerja (Baedi, 2015). Salah seorang pejabat negeri ini pernah mengatakan bahwa jika negeri ini mau maju dibutuhkan sekitar 4 juta orang pengusaha, artinya jumlah pengusaha di Indonesia masih jauh dari angka tersebut. Seorang sosiolog bernama David McCleland mengemukakan bahwa apabila sebuah Negara ingin makmur, minimal sejumlah $2 \%$ dari presentase keseluruhan penduduk di Negara tersebut harus menjadi wirausahawan. Berdasarkan riset saat ini jumlah penduduk Indonesia yang menjadi wirausaha hanya sekitar $0,18 \%$.

Salah satu sasaran yang harus diasah kemandiriannya melalui kegiatan berwirausaha adalah anak-anak yatim yang kurang mampu. Sebagian besar anak yatim mengalami kesulitan dalam mengakses pendidikan maupun ketrampilan (Zubaidah, 2016). Mereka yang tinggal di panti asuhan umumnya minim ketrampilan yang dapat membawa mereka ke taraf kehidupan yang lebih baik.

Berdasarkan permasalahan di atas, penulis akan mengadakan pelatihan kewirausahaan dan ketrampilan bagi anak-anak yatim yang kurang mampu sebagai bentuk kontribusi nyata dalam usaha memandirikan dan memberdayakan mereka. Hal itu kami lakukan mengingat perbuatan menyantuni anak yatim dalam hal memberikan ilmu kemandirian berwirausaha dan ketrampilan adalah salah satu usaha yang sangat dianjurkan oleh agama dan sangat dibutuhkan oleh anak-anak tersebut. Selain itu, kelak mereka akan mampu membuka lapangan pekerjaan baru yang dapat menyerap orang lain yang senasib.

Dalam hal ini peneliti memberi pelatihan kepada remaja putri yang tinggal di Panti Asuhan Siti Hajar Madiun yang berusia 10 tahun keatas karena anak-anak seusia itu mempunyai tingkat kreativitas yang tinggi dan belum mendapatkan materi kewirausahaan yang akan membantu mereka menghadapi persaingan yang semakin ketatdalam bidang pekerjaan. Sedangkan ketrampilan yang akan diberikan adalah kreasi inovatif dari kain flannel karena usaha kain flanel memiliki prospek yang cukup baik, banyak konsumennya, mudah pembuatannya, dan modal yang diperlukan tidak terlalu besar.

\section{B. METODEPELAKSANAAN}

Metode pelaksanaan pelatihan BASHO KANEL (Baby Shoes Kain Flanel) yaitu sosialisasi dan pendampingan. Prosedur pelaksanaan dalam PKM-M ini adalah :

1. Konsultasi

Konsultasi dengan dosen pembimbing mengenai judul program, langkah-langkah penyusunan program, serta rencana pengalokasian dana.

2. Observasi awal ke daerah sasaran 
Kegiatan ini berupa konsultasi awal dengan pengurus yayasan mengenai perijinan tempat dan pengumpulan data anak.

3. Perancangan program

Menyusun program yang akan dilaksanakan seperti pelatihan BASHO KANEL, penyusunan jadwal, penataan tempat, serta pengalokasian dana yang akan digunakan dalam program ini.

4. Pelaksanaan program

Melaksanakan kegiatan pelatihan BASHO KANEL (Baby shoes kain flanel) sesuai dengan jadwal.

5. Evaluasi program

Mengevaluasi kekurangan dan kelebihan kinerja pelatihan BASHO KANEL dan penyusunan rencana tindak lanjut.

6. Pembuatan laporan akhir

Di akhir kegiatan, membuat laporan pertanggung jawaban hasil kerja pelatihan BASHO KANEL.

7. Publikasi

Publikasi pelatihan BASHO KANEL ke media massa maupun media sosial.

Secara garis besar program ini terbagi menjadi 3 tahapan, yaitu:

1. Tahap Pra Pelaksanaan

a. Konsultasi dengan dosen pembimbing mengenai judul program, langkah-langkah penyusunan program, serta rencana pengalokasian danakonsultasi awal dengan masyarakat sasaran mengenai perijinan tempat dan pengumpulan data anak serta melakukan koordinasi kepada pihak yang bersangkutan.

b. Menyusun program yang akan dilaksanakan dalam pelatihan BASHO KANEL.

c. Menyiapkan alat dan bahan untuk pelatihan BASHO KANEL.

2. Tahap Pelaksanaan

Kegiatan pelatihan BASHO KANEL akan diadakan seminggu 1 kali pertemuan dengan alokasi waktu selama 1 jam. Jadi dalam 2 bulan, akan diadakan 8 kali pertemuan. Pada pertemuan pertama dan kedua, peserta pelatihan akan diberikan materi berupa modul. Penyampaian materi menggunakan media PowerPoint disertai potret-potret wirausahawan yang telah sukses. Materi diberikan oleh ketua dan anggota pelaksana pengabdian. Pada pertemuan ketiga sampai keenam, peserta akan diberikan materi keterampilan dan langsung mempraktekkannya dengan alat dan bahan yang telah disediakan. Keterampilan yang akan diberikan berupa pembuatan sepatu bayi dengan bahan dasar kain flannel. Pada pertemuan ketujuh dan kedelapan, peserta akan melaksanakan kegiatan pemasaran produk-produk yang telah mereka buat kepada masyarakat sekitar. Kegiatan pemasaran ini berguna dalam membentuk mental wirausaha mereka.

3. Tahap Pasca Pelaksanaan

Setelah pelaksanaan program pelatihan BASHO KANEL akan dilaksanakan :

a. Evaluasi program 
Mengevaluasi kekurangan dan kelebihan kinerja BASHO KANEL dan penyusunan rencana tindak lanjut.

b. Pembuatan laporan akhir

Di akhir kegiatan, membuat laporan pertanggung jawaban hasil kerja BASHO KANEL.

c. Publikasi

Publikasi pelatihan BASHO KANEL ke media massa maupun media sosial.

4. Implementasi

Pelatihan Basho Kanel di lakukan untuk menyiapkan kewirausahaan remaja putri yang siap berkompetisi secara sehat dan sesuai tuntunan agama. Memandirikan anak yatim agar kelak mereka memiliki keterampilan yang dapat digunakan untuk mencari rezeki. Menumbuhkan semangat kreativitas dalam mengolah kain flannel menjadi suatu produk yang memiliki nilai jual.

5. Output

Pelatihan Basho Kanel ini nantinya dapat menciptakan remaja putri di Panti Asuhan Siti Hajar Madiun yang terampil menjahit kain flannel, kreatif dalam menciptakan produk-produk kreasi flannel yang layak jual. Memiliki pengetahuan tentang wirausaha serta mampu menjadi pengusaha sukses dengan tetap mempertahankan nilai-nilai islami. Publikasi pelatihan "BASHO KANEL" (baby shoes kain flanel) sebagai bekal wirausaha mandiri bagi remaja putri panti asuhan siti hajar madiun pada jurnal yang mempunyai ISSN. Seminar hasil program kreativitas mahasiswa pelatihan "BASHO KANEL" (baby shoes kain flanel) sebagai bekal wirausaha mandiri bagi remaja putri panti asuhan siti hajar madiun.

\section{HASIL DAN PEMBAHASAN}

\section{Waktu Pelatihan}

Kegiatan pelatihan BASHO KANEL dimulai pada tanggal 14 Mei 2017. Pelatihan ini dilaksanakan seminggu 1 kali pertemuan dengan alokasi waktu selama 1 jam. Pada pertemuan pertama dan kedua, peserta pelatihan diberikan materi berupa modul. Penyampaian materi menggunakan media PowerPoint disertai potret-potret wirausahawan yang telah sukses. Materi diberikan oleh ketua dan anggota pelaksana PKM-M. Pada pertemuan ketiga sampai keenam, peserta diberikan materi keterampilan dan langsung mempraktekkannya dengan alat dan bahan yang telah disediakan. Keterampilan yang diberikan berupa pembuatan sepatu bayi dengan bahan dasar kain flannel.

\section{Tempat Pelatihan}

Tempat pelatihan Basho Kanel ini terletak di Panti Asuhan Siti Hajar yang berada di Jalan Jonggrang, Mangunharjo kota Madiun. Dengan kegiatan pelatihan kewirausahaan dan keterampilan ini diharapkan dapat memberikan kontribusi nyata dalam memandirikan mereka. Berdasarkan jadwal kegiatan yang telah tim susun, maka keberhasilan program pengabdian kami dapat dilihat sebagai berikut: 
a. Kegiatan mengenalkan pentingnya berwirausaha kepada peserta pelatihan

Kegiatan pengenalan kewirausahaan kepada peserta pelatihan di Panti Asuhan Siti Hajar Madiun dilakukan dengan memberikan materi berupa pentingnya pengenalan kewirausahaan, apa saja manfaat jika kita melakukan wirausaha dan sekaligus memberikan motivasi kepada anak-anak di panti asuhan siti hajar agar mereka memiliki semangat untuk berwirausaha. Berikut adalah kutipan materi yang di sampaikan dalam pengenalan berwirausaha. "Kewirausahaan merupakan usaha kreatif yang dibangun berdasarkan inovasi untuk menghasilkan sesuatu yang baru, memiliki nilai tambah memberi manfaat, menciptakan lapangan kerja dan berguna bagi orang lain"( Buchari Alma dalam bukunya yang berjudul "Kewirausahaan") . Pembangunan di Indonesia akan lebih mudah jika ditunjang oleh wirausahawan yang dapat membuka lapangan pekerjaan. Wirausaha merupakan potensi pembangunan, baik dalam jumlah maupun dalam mutu wirausaha itu sendiri (Nadlir, 2016), (Suwena, 2016). Sekarang ini kita menghadapi kenyataan bahwa jumlah wirausaha di Indonesia masih sedikit. Jika kita perhatikan manfaat berwirausaha banyak sekali. Menurut Eddy Soeryanto Soegoto (2009) beberapa diantaranya adalah menambah lapangan pekerjaan sehingga dapat mengurangi pengangguran. Memiliki penghasilan sendiri. Menjadi contoh yang baik bagi masyarakat lain. Berwirausaha dapat dilakukan sejak dini. Usia muda merupakan usia-usia yang paling baik untuk belajar, tidak hanya belajar mata pelajaran yang ada di bangku sekolah, akan tetapi belajar berwirausaha juga sangat baik kalau sedari kecil sudah dipelajari (Muttaqiin, Agustina, \& Khusnah, 2018).

Keterampilan berwirausaha satu aspek penting untuk bekal kemandirian saat dewasa kelak. Dengan kegiatan pelatihan kewirausahaan dan keterampilan ini diharapkan dapat memberikan kontribusi nyata dalam memandirikan. Hal-hal yang harus di miliki seseorang untuk menjadi seorang wirausaha yaitu seorang wirausaha harus memiliki keberanian dalam memiliki daya kreasi atau tidak takut untuk bermimpi dan merencanakan (Sukirman, 2017). Harus berani mengambil resiko dan memiliki semangat dan kemauan yang keras untuk sukses.

b. Pelatihan membuat sepatu bayi dari kain flanel

Pelatihan BASHO KANEL diadakan seminggu 1 kali pertemuan dengan alokasi waktu selama 1 jam. Pada pertemuan pertama dan kedua, peserta pelatihan diberikan materi berupa modul. Penyampaian materi menggunakan media PowerPoint disertai potret-potret wirausahawan yang telah sukses. Materi diberikan oleh ketua dan anggota pelaksana PKM-M. Pada pertemuan ketiga sampai keenam, peserta diberikan materi keterampilan dan langsung mempraktekkannya dengan alat dan bahan yang telah disediakan. Keterampilan yang akan diberikan berupa pembuatan sepatu bayi dengan bahan dasar kain flannel. Peserta pelatihan diajarkan membuat bentuk sepatu yang sederhana. 
c. Evaluasi

Evaluasi dilakukan setiap akhir pembinaan di minggu ke 2 masingmasing bulan. Sehingga mampu ada perbaikan kerja dan solusi,hambatan kendala yang selama ini dilakukan. Kegiatan evaluasi ini sangat efisien bagi tim pengabdian karena bersifat evaluatif dan konstributif. Evaluasi ini terbagi atas administratif, teknis dan tim pengabdian. Evaluasi administratif berupa kesalahan dalam cetak, salah penulisan dalam $\log$ book. Evaluasi teknis seperti pengolahan kolaborasi pembelajaran.

d. Laporan

Laporan pengabdian dilaksanakan pada laporan akhir yang dilakukan pada bulan ke-tiga di setiap minggu dan bersamaan dengan kaderisasi pelatihan. Laporan ini meliputi, dokumentasi, perijinan pembinaan, monitoring internal dan perbaikan laporan kemajuan hingga pengunggahan laporan akhir.

\section{KESIMPULAN}

Program Kreatifitas Mahasiswa bidang Pengadian kepada Masyarakat (PKM-M) yang berjudul "pelatihan "BASHO KANEL" (baby shoes kain flanel) sebagai bekal wirausaha mandiri bagi remaja putri panti asuhan Siti Hajar Madiun" ini untuk menyiapkan bekal kewirausahaan bagi remaja putri di sana yang nantinya siap untuk berkompetisi secara sehat dalam dunia bisnis tentunya juga berpegang pada nilai-nilai agama yang telah mereka dapat selama di panti asuhan. Kegiatan pelatihan ini sekaligus dapat menumbuhkan sifat kemandirian kepada anak-anak dip anti asuhan siti hajar, sehingga mereka tidak bergantung kepada orang lain, bahkan mereka dapat memiliki penghasilan sendiri dari keterampilan yang mereka dapatkan dalam pelatihan tersebut. Program ini juga bermaanfaat bagi remaja putri di Panti Asuhan Siti Hajar Madiun yang terampil menjahit kain flannel, kreatif dalam menciptakan produk-produk kreasi flannel yang layak jual.

\section{UCAPAN TERIMA KASIH}

Tim penulis mengucapkan terima kasih kepada Kemenristek DIKTI yang telah mendanai kegiatan pengabdian ini sehingga terlaksana dengan baik.

Tim penulis juga mengucapkan terima kasih kepada pimpinan dan remaja Panti Asuhan Siti Hajar Madiun yang telah menyediakan tempat dan mengikuti pelatihan Basho Kanel sehingga program ini berjalan dengan lancar. Dan tak lupa tim penulis mengucapkan terima kasih kepada LPPM Universitas PGRI Madiun yang telah mendukung dan memberikan bantuan atas terlaksananya kegiatan pengabdian masyarakat ini dengna baik.

\section{REFERENSI}

Baedi, Z. (2015). Urgensi Pendidikan Entrepreneurship Di Kalangan Mahasiswa Ptai. Jurnal Nuansa.

Mentari, D. (2018). Pemberdayaan Masyarakat Sebagai Terobosan Dalam Berwirausaha Untuk Memanfaatkan Sumber Daya Alam. Jurnal Pemberdayaan: Publikasi Hasil Pengabdian Kepada Masyarakat, 1(1), 84. https://doi.org/10.12928/jp.v1i1.318 
Muttaqiin, N., Agustina, H., \& Khusnah, H. (2018). Perencanaan Keuangan Pribadi Untuk Remaja. Jurnal Unusa, 2(1), 17-20.

Nadlir, M. (2016). Urgensi pembelajaran berbasis kearifan lokal. Jurnal Pendidikan Agama Islam (Journal of Islamic Education Studies), 2(2), 299. https://doi.org/10.15642/pai.2014.2.2.299-330

Sukirman, S. (2017). Jiwa Kewirausahaan dan Nilai Kewirausahaan Meningkatkan Kemandirian Usaha melalui Perilaku Kewirausahaan. Jurnal Ekonomi Dan Bisnis, 20(1), 117. https://doi.org/10.24914/jeb.v20i1.318

Suwena, K. R. (2016). Pentingnya Penilaian Potensi Diri Wirausaha Sebagai Pondasi Untuk Mensukseskan Program Mahasiswa Wirausaha (PMW). Jurnal Ilmu Sosial Dan Humaniora, 4(2). https://doi.org/10.23887/jishundiksha.v4i2.6385

Zubaidah, S. (2016). Ibm Kelompok Wirausahawan Muda Working Paper Pengabdian FEB. Studi Kasus Inovasi Ekonomi, 1(1). https://doi.org/10.22219/skie.v1i1.4448

\section{DOKUMENTASI KEGIATAN}

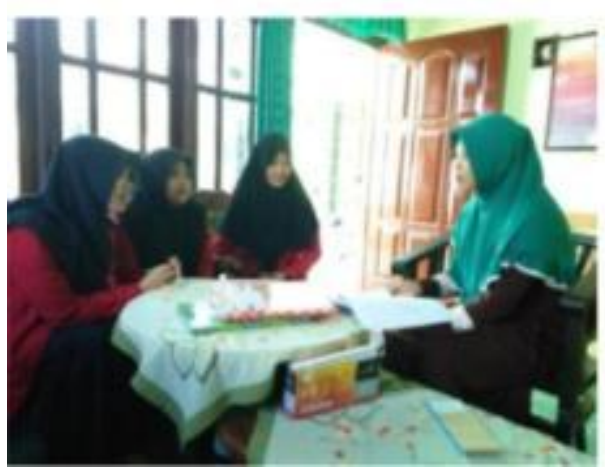

Proses perijinan kepada Kepala

Panti Asuhan Siti Hajar Madiun

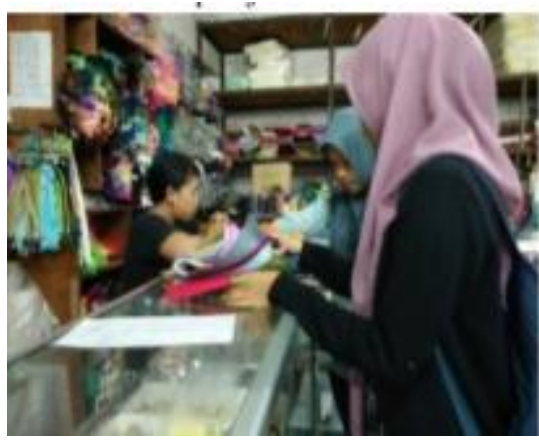

Pembelian alata dan bahan pelatihan Basho Kanel

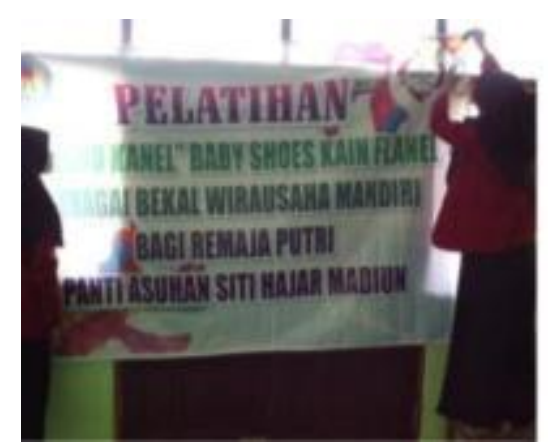

Persiapan dan penyuluhan pelatihan 


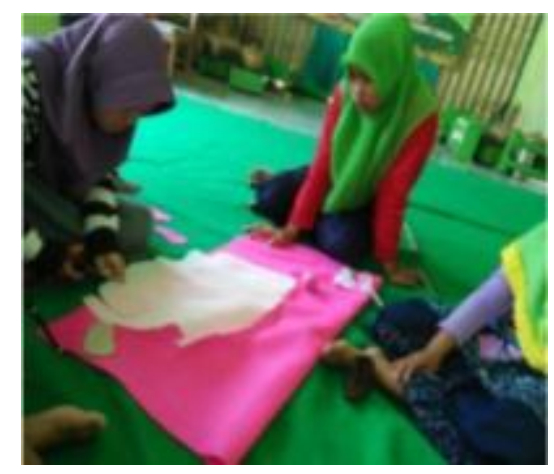

Kegiatan 1

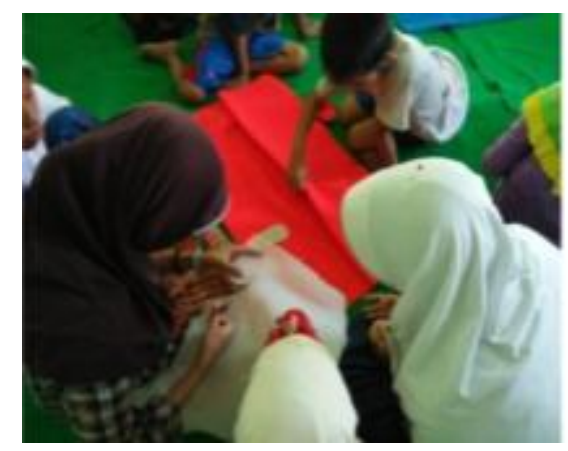

Kegiatan 2

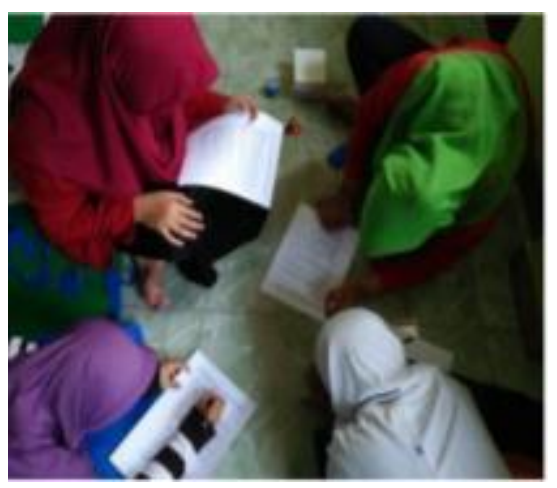

Pengisian angket

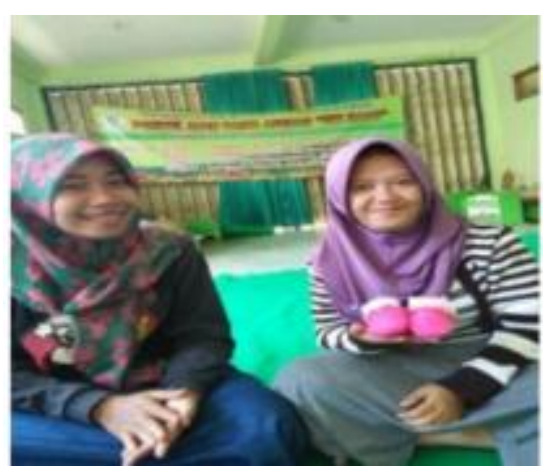

Hasil Produk Pelatihan 